\title{
SOME ASPECTS OF WESTERN HEMLOCK AIR PERMEABILITY
}

\author{
Prasad Rayirath $^{1}$, Stavros Avramidis ${ }^{2}$
}

\begin{abstract}
Knowledge of the variability of fluid permeability of wood in general and of western hemlock in particular is of significant importance to the primary and secondary wood products processing industry of coastal British Columbia. For the purpose of this study, ten hemlock trees were randomly selected and specimens were prepared from three tree heights from each tree, namely, 1, 4 and $7 \mathrm{~m}$. The air permeability of sapwood and heartwood in the longitudinal direction was measured using a dynamic method. Tracheid lengths were also obtained with a fiber quality analyzer and densities were measured by water displacement. The effect of tree height, tracheid length and density on the specific permeability of gross wood was then evaluated. The data revealed that height within the range measured has no effect on longitudinal permeability on heartwood whereas in sapwood the longitudinal permeability increases above $4 \mathrm{~m}$ of tree height. It was also found that longitudinal permeability was not significantly influenced by the tracheid length and wood density.
\end{abstract}

Keywords: Permeability, heartwood, sapwood, western hemlock, tracheid length, density

\section{INTRODUCTION}

Western hemlock (Tsuga heterophylla) is an important coastal species in British Columbia (B.C.) because it is one of the commercially valuable and highly demanded species in world markets, particularly in Asia (Perez-Garcia and Barr 2005). An important characteristic of hemlock is its good treatability with fluids, but in spite of such reputation, hemlock still varies quite widely in its receptivity to treatment (Cooper 1973, Kumar and Morrell 1989). The reasons for this variability remain unclear, while it has been suggested that treatability is a function of anatomical structure, forest site and elevation (Miller 1961). Moreover, the presence of wet pockets and juvenile wood in the heartwood zone and differences in internal wood structure could be possible causes for the variations in permeability and thus, treatability of hemlock. Although this variability exists, there is little information known on the relative differences in permeability within hemlock (Erickson and Crawford 1959, Erickson 1960). Since hemlock is one of the important B.C. coastal species that has been successfully dried in radio frequency vacuum dryers in large cross-sectional sizes where longitudinal permeability becomes the most important factor controlling the rate of water loss is also a significant reason for a better understanding of its variability for fluid flow within its structure (Avramidis 1999).

In conifers, the bordered pits are the principal pathways through which fluids move from one tracheid to the next and therefore pore radii (lumen, pit, margo) and tracheid length have a significant influence on this movement (Nicholas and Siau 1973). While a large number of studies have shown good correlation between permeability and pore radii, lack of significant scientific investigation on the relationship between tracheid length and permeability is evident in the literature (Bains et al. 1983,

\footnotetext{
${ }^{1}$ Graduate student. Department of Wood Science. University of British Columbia. Vancouver, Canada

${ }^{2}$ Professor. Department of Wood Science.University of British Columbia, Vancouver, Canada

Corresponding author: stavros.avramidis@ubc.ca

Received: 30.05. 2008. Accepted: 21.07. 2008
} 
Petty 1970). As wood density is highly determined by the type of cells and extractive deposition in tracheids, it is likely that density can also have a direct impact on permeability (Ryan et al. 2003, Taras and Saucier 1967).

Differences between longitudinal and transverse permeability are well documented in the literature with the former being much higher and in some cases higher by a factor of almost 40000 . This is the result of the anatomical differences along the three axes as explained in detail in Siau (1995). Finally, variation in permeability with tree height has also been investigated with contradictory results in the past. Isaacs et al. (1971) found that there is an increasing trend of permeability with tree height in cottonwood, while Chen and Tang (1991) observed no significant effect of tree height on permeability in three hardwoods.

The objective of this study was to investigate the variability in longitudinal air permeability of sapwood and heartwood western hemlock, and to quantify the effect of tree height, tracheid length and wood density on measured longitudinal permeability.

\section{MATERIALS AND METHODS}

Ten hemlock trees, grown in Harris Creek, B.C., were randomly harvested and from the logs a 50-mm thick disk was cut at three different heights, namely, 1, 4 and 7 meters from each tree. The average age and height of the trees was 85 years and 25.7 meters, respectively. The north face of each trunk was identified and the disks were marked and divided into 4 quadrants, namely, North-East (NE), South-East (SE), North-West (NW) and South-West (SW). The sapwood and heartwood longitudinal permeability specimens of 20x20x35mm in dimension were cut out from each quadrants of the disc using a band saw. All specimens were conditioned to about $10 \%$ to reduce any possible moisture content effects. The NS direction specimens were used to measure longitudinal permeability and density variation across the tree cross-section. The first and fifth specimen from each end of the NS and EW directions, were used to study the effect of tree height, tracheid length and density on permeability. The cutting pattern is illustrated in Figure 1.

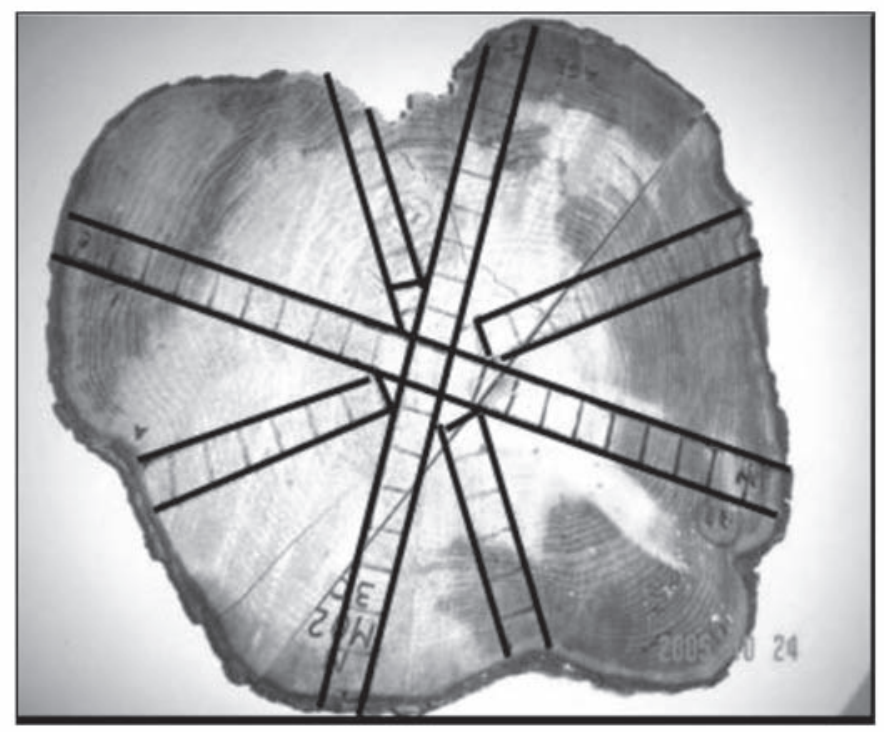

Figure 1: The cutting pattern in north-south-east-west directions of the longitudinal permeability specimens 
The Falling Water Displacement Method (FWDM) as explained in detail in Siau (1995) was used to measure superficial air permeability. The apparatus for this method consists of a large aluminum water tank and a cylindrical glass column which is mounted on a wooden platform above the water tank. The glass column is connected to a vacuum pump and to the specimen holder by means of interchangeable vacuum tubes. The end of the line where the specimen is located is a high vacuum hose. The specimen is inserted in that hose (fits very tight) and hose clamps are used to make a tight seal thus allowing only one-directional air flow through the rectangular specimens shown in Figure 1. The schematic diagram of the apparatus is given in Figure 2. When the vacuum is turned off, air flows through the specimen and into the glass column, which results in the drop of water in the glass column. The time required for the level of water to drop by $\Delta z$ was recorded and used to measure the superficial permeability $(k)$ in $\mathrm{m}^{3}$ (gas)/m s Pa, by using the equation

$$
k=\frac{V_{d} C L\left(P_{a t m}-0.074 \bar{z}\right)}{t A(0.074 \bar{z})\left(P_{a t m}-0.037 \bar{z}\right)} \frac{0.760 m \mathrm{Hg}}{1.013 \times 10^{5} \mathrm{~Pa}}
$$

where $V_{d}=\pi \mathrm{r}^{2} \Delta \mathrm{z}$ is the volume of gas displaced by water in the glass column, $\left(\mathrm{m}^{3}\right) ; \Delta z$ is the distance between the two marked points in the glass column, $(\mathrm{m}) ; \mathrm{P}_{\mathrm{atm}}$ is the atmospheric pressure $(\mathrm{Pa})$; $L$ is the length of the specimen, $(\mathrm{m}) ; \bar{z}$ is the average height of water over surface of the reservoir during period of measurement, (m); $\mathrm{t}$ is time, $(\mathrm{s}) ; A$ is the area of cross-section of the specimen, $\left(\mathrm{m}^{2}\right)$ and $C$ is the correction factor

$$
\mathrm{C}=1+\frac{V_{r}(0.074 \Delta z)}{V_{d}\left(P_{a t m}-0.074 \bar{z}\right)}
$$

where $V_{r}$ is the total volume above point 1 (see Figure 2) including hoses $\left(\mathrm{m}^{3}\right)$. The specific permeability $(K)$ of the specimens was calculated by the product of superficial permeability and viscosity of air $\left(1.81 \times 10^{-5} \mathrm{~Pa} \mathrm{~s}\right.$ at $\left.20^{\circ} \mathrm{C}\right)$.

$$
K=k \mu
$$

where $\mu$ is the viscosity of air (Pa s) and $K$ measured in $\mathrm{m}^{3} / \mathrm{m}$.

The length of the wood tracheids was measured using an OpTest Laboratory Fiber Quality Analyzer (FQA) that utilizes circular polarized light to project images of the tracheids and thus automatically measures the tracheid length. For these measurements, a small sample taken from each of the 240 specimens (1st and 5th specimen from each end of NS and EW directions of each disc), was cut out using a chisel and then soaked in 50\% Franklin solution (glacial acetic acid equivalent to 6\% hydrogen peroxide), and digested at $70^{\circ} \mathrm{C}$ for approximately 24 hours. Before measuring the tracheid length, a suspension solution was prepared after washing, disintegrating and diluting the digested wood pulp with water. In FQA, as the suspension solution joins the water casing and passes through the optics box, the digital camera takes pictures of the tracheid projections and calculates the weighted average of tracheid length for each specimen. 


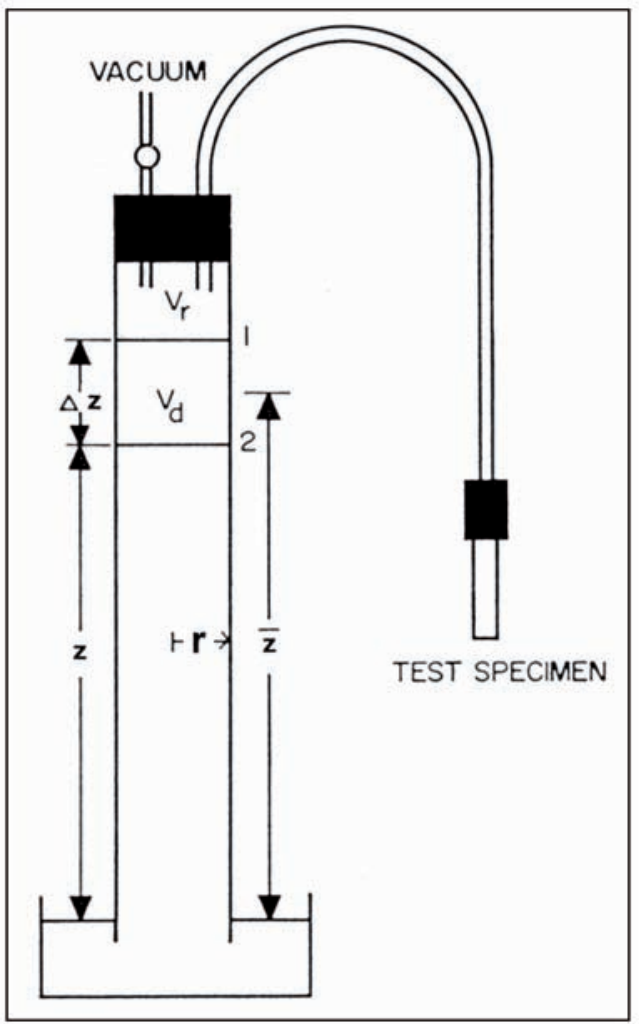

Figure 2: Schematic diagram of the falling-water permeability apparatus with corresponding model parameters (from Siau 1995)

The density of the specimens in NS direction of each disc was measured using the standard water displacement method.

\section{RESULTS AND DISCUSSION}

The variation in inherent properties of wood such as xylem anatomy can result in variation of permeability both within and between trees (Gartner et al. 2002, Panshin and de Zeeuw 1980). The overall specific permeability (thereafter referred in this manuscript as "permeability") in this study ranged from 0.02 to $2.34 \mu \mathrm{m}^{3} / \mu \mathrm{m}$ in which the heartwood specimens showed a range of 0.0158 to $0.38 \mu \mathrm{m}^{3} /$ $\mu \mathrm{m}$, whereas for sapwood specimens this range was 0.12 to $2.34 \mu \mathrm{m}^{3} / \mu \mathrm{m}$. The average permeability of heartwood and sapwood specimens at three different heights is listed in Table 1 . The data analysis was conducted using a factorial experimental design with height, type of specimen, and direction as dependent factors. 
Table 1: The average values of permeability and tracheid length at different tree height.

\begin{tabular}{|c|c|c|c|c|c|c|c|c|}
\hline Tree height & \multicolumn{3}{|c|}{$\begin{array}{c}\text { Average longitudinal specific } \\
\text { permeability }\left(\boldsymbol{\mu m ^ { 3 }} / \boldsymbol{\mu m}\right)\end{array}$} & \multicolumn{4}{c|}{$\begin{array}{c}\text { Average tracheid } \\
\text { length(mm) }\end{array}$} \\
\hline & \multicolumn{2}{|c|}{ Sapwood } & \multicolumn{2}{c|}{ Heartwood } & \multicolumn{2}{c|}{ Sapwood } & \multicolumn{2}{c|}{ Heartwood } \\
\hline & Average & SD & Average & SD & Average & SD & Average & SD \\
\hline $\mathbf{1 m}$ & 1.112 & 0.482 & 0.068 & 0.044 & 3.070 & 0.225 & 2.089 & 0.296 \\
\hline $\mathbf{4 m}$ & 1.018 & 0.383 & 0.073 & 0.064 & 3.086 & 0.286 & 2.137 & 0.263 \\
\hline $\mathbf{7 m}$ & 1.421 & 0.513 & 0.070 & 0.066 & 3.138 & 0.232 & 2.087 & 0.266 \\
\hline All specimens & $\mathbf{1 . 1 8 4}$ & $\mathbf{0 . 4 9 2}$ & $\mathbf{0 . 0 7 0}$ & $\mathbf{0 . 0 5 8}$ & $\mathbf{3 . 0 9 8}$ & $\mathbf{0 . 2 4 4}$ & $\mathbf{2 . 1 0 4}$ & $\mathbf{0 . 2 7 5}$ \\
\hline
\end{tabular}

At all selected heights, the sapwood specimens showed significantly (99\% level) higher permeability value than the heartwood specimens (Table 2). The lower permeability of heartwood might be due to the high degree of aspiration in the bordered pits and also the incrustation of the bordered pit membranes (Koumoutsakos and Avramidis 2002).

Table 2: ANOVA for longitudinal permeability of sapwood and heartwood specimens

\begin{tabular}{|c|c|c|c|c|c|}
\hline Source & DF & Type III SS & Mean Square & F Value & Pr $>$ F \\
\hline $\mathrm{H}$ & 2 & 1.77 & 0.89 & 8.06 & 0.0004 \\
\hline $\mathrm{D}$ & 3 & 0.39 & 0.13 & 1.19 & 0.3138 \\
\hline $\mathrm{S}$ & $\mathbf{1}$ & $\mathbf{7 4 . 4 5}$ & $\mathbf{7 4 . 4 5}$ & $\mathbf{6 7 6 . 0 8}$ & $<.0001$ \\
\hline $\mathrm{H}^{*} \mathrm{D}$ & 6 & 0.54 & 0.09 & 0.82 & 0.5527 \\
\hline $\mathrm{H}^{*} \mathrm{~S}$ & $\mathbf{2}$ & $\mathbf{1 . 7 9}$ & $\mathbf{0 . 8 9}$ & $\mathbf{8 . 1 4}$ & $\mathbf{0 . 0 0 0 4}$ \\
\hline $\mathrm{D} * \mathrm{~S}$ & 3 & 0.34 & 0.11 & 1.03 & 0.3784 \\
\hline $\mathrm{H}^{*} \mathrm{D} * \mathrm{~S}$ & 6 & 0.44 & 0.07 & 0.67 & 0.6779 \\
\hline & & & & & \\
\hline Model & $\mathbf{2 3}$ & $\mathbf{7 9 . 7 3}$ & $\mathbf{3 . 4 6}$ & $\mathbf{3 1 . 4 8}$ & $<.0001$ \\
\hline Error & $\mathbf{2 1 6}$ & $\mathbf{2 3 . 7 8}$ & $\mathbf{0 . 1 1}$ & & \\
\hline Total & $\mathbf{2 3 9}$ & $\mathbf{1 0 3 . 5 1}$ & & & \\
\hline
\end{tabular}

$\mathrm{S}=$ Section (Sapwood and Heartwood); D=Direction (North, South, East and West); H=Height (1m, 4m and 7m)

The average permeability of sapwood and heartwood at different tree heights is plotted in Figure 3. The statistically significant difference between average permeability of heartwood and sapwood at all three heights is apparent. For sapwood permeability, statistical analysis revealed significant differences only between the average permeability at $7 \mathrm{~m}$ compared to sapwood at 1 and $4 \mathrm{~m}$ height. Nevertheless, the average permeability of 1 and $4 \mathrm{~m}$ specimens showed no significant difference among them. The results are somewhat similar to those reported by Comstock (1965) for eastern hemlock where permeability increased with increasing tree height. Variation in permeability with tree height has been investigated with contradictory result in the past. Isaacs et al. (1971) found that there is an increasing trend of permeability with tree height in cottonwood, while Chen and Tang (1991) observed no significant effect of tree height on permeability in three hardwoods. The increase in sapwood permeability at 7 meters can be explained by a distinct process known as cambial maturation. In wood, new xylem cells are produced by the divisions of cambial initials which are the meristematic cells found between the xylem and phloem. Cambial maturation is affected by height within the tree and can be described as a developmental process that results in a change in the dimensions of cambial initials over time and affects the dimensions of xylem cells (Panshin and de Zeeuw 1980, Fabris 2000). As permeability is dependent on the dimension of the tracheid cells, any change in them will also affect the permeability of the wood. 


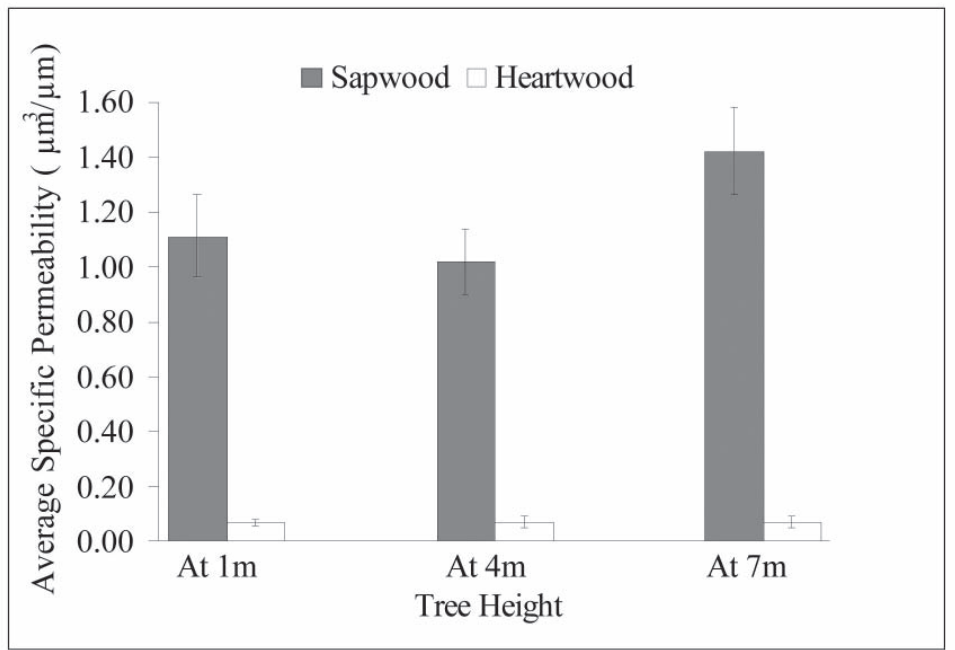

Figure 3: Comparison of longitudinal permeability between heartwood and sapwood at different tree heights and error bar represents the confidence at $95 \%$

Heartwood permeability showed no trend and difference as a function of tree height clearly indicating that no detectable variability in pit occlusions exists within this wood type along the trunk of a hemlock tree up to 7 meters height.

The effect of tracheid length and density on longitudinal permeability was also studied. As in permeability, the data analysis for tracheid length was carried out using a factorial experiment with height, type of specimen, and direction as factors. The correlation analysis was also conducted to observe if any relationship exist between the permeability and tracheid length. The overall range of tracheid length for all wood specimens was 1.30 to $3.66 \mathrm{~mm}$ in which 2.03 to $3.66 \mathrm{~mm}$ range was observed for sapwood and 1.30 to $2.88 \mathrm{~mm}$ for heartwood specimens. The average tracheid lengths at three different tree heights are plotted in Figure 4. At all investigated heights, the average tracheid length of sapwood is significantly longer compared to that of heartwood specimens $(P \leq 0.05)$.

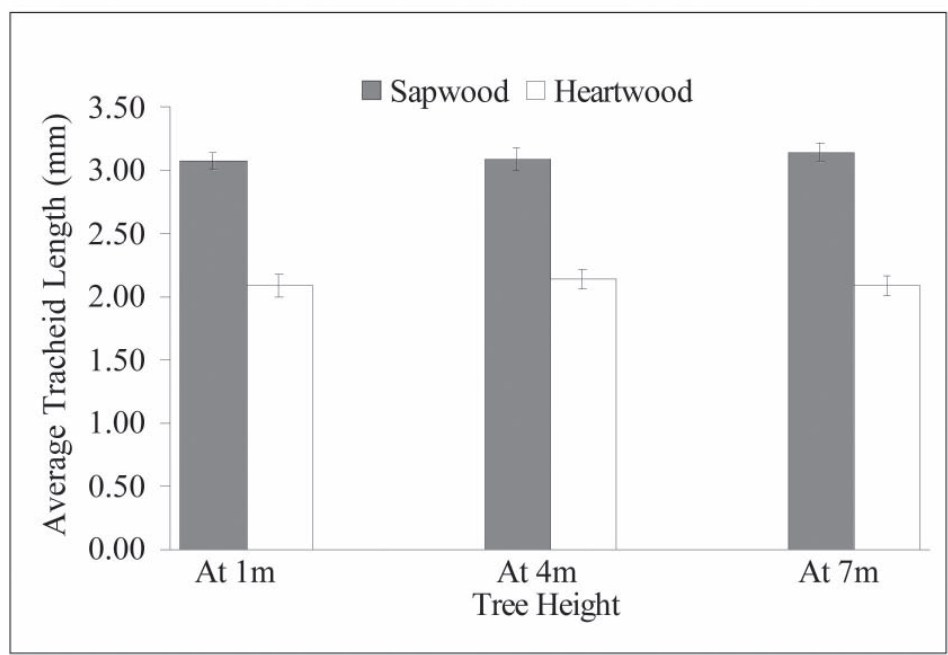

Figure 4: Comparison of tracheid length between heartwood and sapwood at different tree heights and error bar representing confidence at $95 \%$ 
This difference between sapwood and heartwood can be attributed to the increase in length of the cambial initials with age combined with an enhanced intrusive growth (Honjo et al. 2006). It was also apparent that tree height has no effect on tracheid length in both sapwood and heartwood specimens.

There have been no significant research efforts that focused on the relation between tracheid length and longitudinal permeability. However, given the fact that fluid movement occurs through the void lumens in the tracheids and then through the pits, it would be interesting to explore the differences in tracheid length and consequent differences in the lumen area that might have an effect on the rate of fluid movement. Theoretically, tracheid length should have an influence on permeability because the longer the tracheid, the fewer end-wall crossings per unit length, and so the higher the permeability (Sperry and Hacke 2004). Our results in both sapwood and heartwood specimens failed to reveal any definite correlation between tracheid length and permeability. Knowing the significant amount of variability when investigating permeability this result should not be taken as a definite one and more work must be carried out to reveal this relationship in the future.

The density of hemlock specimens at three different heights were measured and shown to range from $341-854 \mathrm{~kg} / \mathrm{m}^{3}$ with average density of $469 \mathrm{~kg} / \mathrm{m}^{3}$ and standard deviation of 68.6 . It was observed that the density is relatively high near the pith, then decreases in the juvenile wood and then again increases when reaching the sapwood. The average density of specimens at 1,4 and $7 \mathrm{~m}$ were found to be 494,459 and $446 \mathrm{~kg} / \mathrm{m}^{3}$, respectively. Although the average density of western hemlock seems to decrease with increasing tree height, the statistical analysis confirms that the only significant differences were $((\mathrm{P} \leq 0.05)$ between $1 \mathrm{~m}$ with that of 4 or $7 \mathrm{~m}$. However, the density between 4 and $7 \mathrm{~m}$ height showed no significant variation between them. The broad range of density values is mainly due to the percentage of earlywood and latewood and differences in their respective density. This trend has also been reported by other researchers in the past (Megraw 1986, Jozsa and Kellogg 1986, Kennedy 1995, Gartner et al. 2002). As wood density is highly affected by the type of cells and extractive deposition in tracheids, it is likely that density can have a direct impact on permeability. However, research has shown that the density has no affect on the permeability (Bao et al. 1994). In this study, no significant correlation was observed between these two properties.

\section{CONCLUSIONS}

In the light of this investigation related to the fluid permeability of western hemlock the following conclusions can be drawn.

- Longitudinal permeability of western hemlock ranged from $0.01-2.34 \mu \mathrm{m}^{3} / \mu \mathrm{m}$. It was observed that the permeability of sapwood was 5 to 200 times higher than that of heartwood.

- The average longitudinal permeability of sapwood at $7 \mathrm{~m}$ height from the ground was found to be significantly higher than that of 1 and $4 \mathrm{~m}$ height whereas the heartwood permeability is not affected by tree height.

- Tracheid length of western hemlock varied from 1.3 to $3.7 \mathrm{~mm}$. Tracheid length does not change significantly with respect to height and no correlation was observed between tracheid length and longitudinal permeability

- Though variation in density is likely to change permeability, in the present study there was no significant relationship observed between density and longitudinal specific permeability. 


\section{REFERENCES}

Avramidis, S. 1999. Radio frequency vacuum drying of wood. In proceedings of the COST E15 Wood Drying Conference, Edinburgh, UK, 125-138.

Baines, E. F.; Woodward, C. J.; Levy, J. F.; Dickinson, D. J. 1983. Indirect measurement of pore size and permeability in Scots pine and Norway spruce. Journal of Experimental Botany 34(143):694704

Bao, F.; Lu, J.; Avramidis, S. 1999. On the permeability of main wood species in China Holzforschung 53: 350-354

Chen, P. Y. S.; Tang, Y. 1991. Variation in longitudinal permeability of three U.S. hardwoods. Forest Products Journal 41(11-12): 79-83.

Comstock, G. L. 1965. Longitudinal permeability of green eastern hemlock. Forest Products Journal 17(10): 441-449

Cooper, P. A. 1973. Effect of species, pre-compression, and seasoning on heartwood preservative treatability of six western conifers. Forest Products Journal 23(7): 51-59

Erickson, H. D.; Crawford, R. J. 1959. The effect of seasoning methods on the permeability of wood to liquids. Proceedings of the American Wood Preservers Association 55: 210-219.

Erickson, H. D. 1960. The effects of storage conditions and time upon permeability of green sapwood. Proceedings of the American Wood Preservers Association 56: 156-165.

Fabris, S. 2000. Influence of cambial ageing, initial spacing, stem taper and growth rate on wood quality of three coastal conifers. Ph.D. Thesis, Faculty of Graduate Studies, Department of Forestry, The University of British Columbia, Vancouver, BC, $250 \mathrm{pp}$.

Gartner, B.L.; North, E.N.; Johnson, G.R.; Singleton, R. 2002. Effects of live crown on vertical patterns of wood density and growth in Douglas-fir. Canadian Journal Forest Research 32(3):439-447

Honjo, K.; Ogata, Y.; Fujita, M. 2006. Introduction and verification of a novel method for measuring wood fiber length using a single cross section in Acacia mangium. Trees 20: 356-362

Isaacs, P.; Choong, E.T.; Fogg, P. J. 1971. Permeability variation within a cotton wood tree. Wood Science 3(4):231-237

Jozsa, L. A.; Kellogg, R.M. 1986. An exploratory study of the density and annual ring width trends in fast-growth coniferous wood in British Columbia. CFS Contract Rept. No. 02-80-55-017. Forintek Canada Corp., Vancouver, BC. pp 43

Kennedy, R.W. 1995. Coniferous wood quality in the future: Concerns and strategies. Wood Science and Technology 29(5): 321-338

Koumoutsakos, A.; Avramidis, S. 2002. Mass transfer characteristics of western hemlock and western red cedar. Holzforschung 53(2):185-190 
Kumar, S.; Morrell, J. J. 1989. Penetration and absorption of different CCA compositions in six western conifers. Forest Products Journal 39(10): 19-24

Megraw, R. A. 1986. Douglas-fir wood properties. In: Proc., Douglas-fir: Stand Management for the Future. Inst. of Forest Resources, Univ. of Washington, Seattle, WA. pp. 81-96.

Miller, D.J. 1961. Permeability of Douglas-fir in Oregon. Forest Products Journal 11(1):14-16

Nicholas, D.D.; Siau, J.F. 1973. Factors influencing the treatability of wood. In Nicholas D.D. (ed) Wood Deterioration and its Prevention by Preservative Treatments. II Preservatives and preservative systems. Syracuse University Press, Syracuse, 299-343

Panshin, A. J.; de Zeeuw, C. 1980. Textbook of Wood Technology, 4th Ed. McGraw-Hill, New York.

Perez-Garcia, J.; Barr, J. K. 2005. Forest products export trends update for the Pacific Northwest region. Discussion paper from University of Washington, College of Forest Resources, Northwest Environmental Forum, Seattle, USA

Petty, J.A. 1970. Permeability and structure of the wood of sitka spruce. Proceedings of the Royal Society of London. Series B, Biological Science 175(1039):149-166

Ryan, S.; Dean, S. D.; Barbara, L.G. 2003. Effect of extraction on wood density of western hemlock (Tsuga heterophylla). Wood and Fiber Science 35(3):363-369

Siau, J. F. 1995. Transport processes in wood. Springer-Verlag Berlin Heidelberg New York Tokyo. pp 245.

Sperry, J. S.; Hacke, U. G. 2004. Analysis of circular bordered pit function. I. Angiosperm vessels with homogenous pit membranes. American Journal of Botany 91: 369-385

Taras, M. A.; Saucier, J.R. 1967. Influence of extractives on specific gravity in southern pines. Forest Products Journal 17:97-99. 
